DOI: http://dx.doi.org/10.33846/ghs6105

\title{
Gambaran Tingkat Pengetahuan Orang Tua Tentang Kenakalan Remaja Di Dusun Liaela Desa Luhu Kecamatan Huamual Kabupaten Seram Bagian Barat Tahun 2018
}

\author{
Luthfy Latuconsina (koresponden) \\ IImu Kesehatan Masyarakat, STIKes Maluku Husada; latuconsinaluthfi@gmail.com \\ Gariman Kurniawan \\ IImu Kesehatan Masyarakat, STIKes Maluku Husada; garimankurniawan@gmail.com \\ Elvans Z Lohy \\ IImu Kesehatan Masyarakat, STIKes Maluku Husada; elvanslohy@gmail.com \\ F Richa Fautngilyanan \\ IImu Kesehatan Masyarakat, STIKes Maluku Husada; richaf@gmail.com
}

\section{ABSTRAK}

Remaja adalah penduduk dalam rentang usia 10-19 tahun, menurut Peraturan Menteri Kesehatan RI Nomor 25 tahun 2014, Tidak semuan orang mempunyai pengaruh yang sama terhadap diri indifidu. Ada yang paling pengaruh, yaitu orang-orang dekat dengan diri individu. Secara perlahan-lahan individu membentuk konsep diri. Penelitian ini bertujuan untuk mengetahui gambaran tingkat pengetahuan orang tua tentang kenakalan remaja di Dusun Liaela Desa Luhu Kecamatan Huamual Kabupaten Seram Bagian Barat. Memetode penelitian deskriptif, dengan berjumlah 95 responden. Hasil dari penelitian ini diperoleh responden dengan pengetahuan baik sebanyak 23 responden dengan persentase $(24,2)$, dan yang cukup sebanyak 28 dengan persentase $(29,5)$ serta responden pengetahuan cukup sebanyak 44 dengan persentase $(46,3)$. Maka dapat disimpulkan bahwa sebagian besar pengetahuan orang tua masi kurang, yaitu sebanyak $(46,3 \%)$.

\section{PENDAHULUAN}

Menurut World Health Organization (WHO), remaja adalah penduduk dalam rentang usia 10-19 tahun, menurut Peraturan Menteri Kesehatan RI Nomor 25 tahun 2014, remaja adalah penduduk dalam rentang usia 10-18 tahun dan menurut Badan Kependudukan dan Keluarga Berencana (BKKBN) rentang usia remaja adalah 10-24 tahun dan belum menikah. Jumlah kelompok usia 10-19 tahun di Indonesia menurut sensus penduduk 2010 sebanyak 43,5 juta atau sekitar 18\% dari jumlah penduduk. Di dunia diperkirakan kelompok remaja berjumlah 1,2 milyar atau $18 \%$ dari jumlah penduduk dunia. ${ }^{(1)}$

Remaja adalah anak pada masa adolesensi yaitu perubahan-perubahan dalam penampilan gerak atau perkembangan motorik antara umur 12-20 tahun (diantara anak-anak dan dewasa). Anak remaja sebenarnya tidak mempunyai tempat yang jelas, tidak termaksut golongan anak-anak, tetapi tidak pula termasuk golongan orang dewasa. Remaja masi belum mampu untuk menguasai fungsifungsi fisik maupun psikisnya. ${ }^{(2)}$ Masa remaja adalah masa transisi dari anak-anak menuju dewasa dan pada masa ini jiwa mereka masih penuh dengan gejolak. Tidak sedikit di antara mereka justru ber perilaku menyimpang, bahkan ada yang menjurus ke seks bebas, tindak kriminal dan penyalahgunaan obat. ${ }^{(3)}$

Faktor yang berpengaruh pada remaja adalah lingkungan, yang meliputi lingkungan keluarga, lingkungan sekolah, serta lingkungan masyarakat sekitarnya. Oleh karena itu orang tua atau orang yang berhubungan dengan remaja perlu mengetahui ciri perkembangan jiwa remaja, pengaruh lingkungan terhadap perkembangan jiwa remaja serta masalah maupun gangguan jiwa remaja pada $15-22 \%$ anak-anak dan remaja, namun yang mendapat pengobatan jumlahnya kurang dari $20 \%$. Diagnosa gangguan jiwa pada anak-anak dan remaja adalah perilaku yang tidak sesuai dengan tingkat usianya, menyimpang bila di bandingkan dengan norma budaya yang mengakibatkan kurangnya atau terganggunya fungsi adaptasi. ${ }^{(4)}$

Penelitian ini bertujuan untuk mengetahui gambaran tingkat pengetahuan orang tua tentang kenakalan remaja di Dusun Liaela Desa Luhu Kecamatan Huamual Kabupaten Seram Bagian Barat.

\section{METODE}

Penelitian yang digunakan merupakan penelitian deskriptif sederhana dengan pendekatan kuantitatif. Deskriptif adalah penelitian yang bertujuan untuk mengetahui gambaran atau deskripsi tentang suatu keadaan secara objektif dan digunakan untuk memecahkan situasi yang sedang 
dihadapi saat ini.(5) Penelitian ini dilakukan untuk mengetahui gambaran tingkat pengetahuan orang tua tentang kenakalan remaja di Dusun Liaela Desa Luhu Kecamatan Huamual Kabupaten Seram Bagian Barat

\section{HASIL}

\section{Umur Responden}

Tabel 1. Distribusi Responden Berdasarkan Umur di Dusun Liaela Desa Luhu Kecamatan Huamual Kabupaten Seram Bagian Barat Tahun 2018

\begin{tabular}{|c|c|c|}
\hline Umur Responden & Frekuensi & Persentase \\
\hline $30-40$ tahum & 32 & 33.7 \\
\hline $41-50$ tahun & 49 & 85.3 \\
\hline$>50$ tahun & 14 & 100.0 \\
\hline Total & 95 & 100.0 \\
\hline
\end{tabular}

Dari total umur anak untuk usia 41-50 tahun adalah yang paling banyak yaitu berjumlah 49 orang dengan persentase (85.3\%).

\section{Jenis Kelamin Responden}

Tabel 2. Distribusi Responden Berdasarkan Jenis Kelamin Di Dusun Liaela Desa Luhu Kecamatan Huamual Kabupaten Seram Bagian Barat Tahun 2018

\begin{tabular}{|c|c|c|}
\hline Jenis kelamin & Frekuensi & Persentase \\
\hline Laki-laki & 38 & 40.0 \\
\hline Perenpuan & 57 & 60.0 \\
\hline Total & 95 & 100.0 \\
\hline
\end{tabular}

Tabel 2 menunjukan bahwa dari 95 responden yang paling banyak berjenis kelamin perenpuan sebanyak 57 orang dengan persentase $(60.0 \%)$.

\section{Pendidikan Responden}

Tabel 3. Distribusi Responden Berdasarkan Tingkat pendidikan Dusun Liaela Desa Luhu Kecamatan Huamual Kabupaten Seram Bagian Barat Tahun 2018

\begin{tabular}{|c|c|c|}
\hline Pendidikan & Frekuensi & Persentase \\
\hline Tidak Sekolah & 11 & 11.6 \\
\hline SD & 13 & 13.7 \\
\hline SMP & 33 & 34.7 \\
\hline SMA & 35 & 36.8 \\
\hline Perguruan tinggi & 3 & 3.2 \\
\hline
\end{tabular}

Tabel 3 menunjukan bahwa dari 95 responden yang paling banyak pendidikan SMA sebanyak 35 orang dengan persentase $(36.8 \%)$.

\section{Pengetahuan}

Tabel 4. Distribusi Responden Berdasarkan Pengetahuan di Dusun Liaela Desa Luhu Kecamatan Huamual Kabupaten Seram Bagian Barat Tahun 2018

\begin{tabular}{|c|c|c|}
\hline Pengetahuan & Frekuensi & Persentase \\
\hline Baik & 23 & 24.2 \\
\hline Cukup & 28 & 29.5 \\
\hline Kurang & 44 & 46.3 \\
\hline Total & 95 & 100.0 \\
\hline
\end{tabular}


Dari data di atas dapat di simpulkan bahwa kurangnya pengetahuan orang tua sebanyak 44 responden dengan persentase $(46.3 \%)$.

\section{Umur dan Pendidikan}

Tabel 5. Distribusi Berdasarkan Responden Umur Dan Pendidikan Kenakalan Remaja di Dusun Liaela Desa Luhu Kecamatan Huamual Kabupaten Seram Bagian Barat Tahun 2018

\begin{tabular}{ccc}
\hline Umur & Frekuensi & Persentase \\
\hline $12-15$ tahun & 17 & 17.9 \\
$16-19$ tahun & 78 & 82.1 \\
\hline Pendidikan & Frekuensi & Persentase \\
\hline Tidak Sekolah & 41 & 43.2 \\
Smp & 21 & 22.1 \\
Sma & 33 & 34.7 \\
\hline Total & 95 & 100.0 \\
\hline
\end{tabular}

Berdasarkan distribusi umur responden yang terbanyak 16-19 tahun (82.1\%), sedangkan berdasarkan pendidikan responden yang terbanyak Tidak Sekolah 41 orang $(43.2 \%)$.

\section{Kenakalan Remaja}

Table 6. Distribusi Responden Berdasarkan Kenakalan Remaja Di Dusun Liaela Desa Luhu Kecamatan Huamual Kabupaten Seram Bagian Barat Tahun 2018

\begin{tabular}{|c|c|c|}
\hline Kenakalan remaja & Frekuensi & Persentase \\
\hline Nakal & 57 & 60.0 \\
\hline Tidak nakal & 38 & 40.0 \\
\hline Total & 95 & 100.0 \\
\hline
\end{tabular}

Dari data di atas dapat di simpulkan bahwa kenakalan remaja nakal sebanyak 57 responden dengan persentase $(60.0 \%)$.

\section{PEMBAHASAN}

\section{Pengetahuan Orang Tua}

Pengetahuan merupakan hasil dari tahu, dan ini terjadi setelah orang melaksanakan pengindraan terhadap suatu objek tertentu, pengindraan terjadi melalui panca indara manusia, yakni panca indra penglihatan, pendengaran, penciuman, rasa dan raba. Sebagian besar pengetahuan manusia di peroleh melalui mata dan telinga.

Hasil penelitian didapatkan bahwa distribusi pengetahuan orang tua yang terbanyak adalah pengetahuan kurang memahami perilaku kenakalan remaja, sebanyak $(46,3 \%)$ dan yang paling sedikit pengetahuan orang tua baik, sebanyak $(24,2 \%)$. Hal ini menunjukan bahwa tingkat pengetahuan orang tua kurang tahu tentang kenakalan remaja dikarenakan orang tua tidak memperhatikan anak hingga menjadi remaja di Dusun Liaela Desa Luhu Kecamatan Huamual Kabupaten Seram Bagian Barat.

\section{Kenakalan Remaja}

Menurut Zakiah Deradjat "kenakalan remaja adalah perbuatan yang tidak baik, perbuatan dosa, maupun sebagai manifentasi dari rasa tidak puas, kegelisahan ialah perbuatan-perbuatan yang menggangu ketenangan dan kepentingan orang lain dan kadang-kadang diri sendiri". Berdasarkan hasil penelitian bahwa kenakalan remaja di Dusun Liaela Desa Luhu Kecamatan Huamual Kabupaten Seram Bagian Bara yaitu nakal $\geq 4$ adalah 57 anak dengan persentase (60.0) kemudian yang kurang baik 4 adalah 38 anak dengan persentase $(40.0 \%)$ 


\section{KESIMPULAN}

Tingkat pengetahuan orang tua tentang kenakalan remaja di Dusun Liaela Desa Luhu Kecamatan Huamual Kabupaten Seram Bagian Barat. Sebagian besar masi Kurang, sebanyak 44 responden. Kenakalan remaja yang terjadi di Dusun Liaela Desa Luhu Kecamatan Huamual Kabupaten Seram Bagian Barat. Berupa tawuran dan sering tidak masuk sekolah, mabuk-mabukan, perkelahian antara desa atau dusun, merokok, sek bebas, dan pencurian.

\section{DAFTAR PUSTAKA}

1. BKKBN. 2016. Kebijakan Program Kependudukan, Keluarga Berencana, dan Pembangunan Keluarga. Jakarta: BKKBN.

2. Sarwono, S.W. (2015). Psikologi remaja. PT Bumi Siliwangi: Bandung

3. Prasetyono. D.S. (2013). Knowing Yourself. Saufa: Yogyakarta

4. Laksono, S.P., Astutik, j. (2015). Kekerasan Gender Dalam Berpacaran Di Kalangan Mahasiswa (Studi Kasus Malang). Jurnal Perempuan Dan Anak.

5. Notoatmodjo, S. (2013). Konsep Perilaku Dan Perilaku Kesehatan. PT Rineka Cipta: Jakarta. 